\title{
Hopes and doubts greet Paris AIDS 'summit'
}

Paris. Leading politicians from 42 nations will meet for an 'AIDS summit' in Paris next week. One outcome will be a declaration committing the signatories to promote prevention - including removal of economic, cultural and other obstacles -- and to adopt national policies to help people who are seropositive and protect their rights.

The declaration will also call for international actions in seven areas, including blood safety, cooperation between public and private sectors in research and development, and social and health-care programmes.

Bernard Debré, chairman of the summit organization committee, and the newly appointed French minister of cooperation, has called the meeting a political "first" and "unusual" in that it will produce "practical action". Debré admits that consensus on areas such as sex education is unattainable, but has described any agreement as "already something".

But many AIDS researchers and activists are concerned that the declaration - which they describe as a "list of good intentions" - may prove both unworkable and ineffective. They claim that the difficulty in getting consensus among 42 countries has made it "lowest common denominator" material. Fewer but firmer commitments would have been preferable, they say, for example to increase funding for AIDS programmes and end discriminatory laws.

Activists argue that the declaration's wording is so ambiguous that even Russia, whose parliament last week approved compulsory HIV screening of foreigners, has few qualms about signing it. Critics also argue that Roman Catholic states could avoid promoting condoms, because a provision calling for "promotion of access to means of prevention", includes the caveat that this should be "culturally acceptable".

Act-Up, one of several activist groups represented on the organizing committee, now describes the meeting as a foregone "failure" and a "step backwards". A member of another group, ARCAT-SIDA, complains that "boosting France's international influence" is now the summit's "sole objective".

Indeed, the meeting has been controversial ever since it was proposed last year by Simone Veil, the French health minister. Many countries opposed it at first, arguing that with various United Nations (UN) agencies combining their AIDS activities into a single programme coordinated by the World Health Organization (WHO), it risked duplicating efforts elsewhere.

Such concern faded in May, when WHO became a coorganizer of the summit and it was agreed to channel any new funds or priorities to emerge into the UN programme. Support from Edouard Balladur, the French prime minister of whom Veil is a political ally, also helped to persuade a meeting of health ministers from the 42 countries -19 from the developed world and 23 from developing nations - in June to back the meeting.

Despite such misgivings, most agree that the summit will boost flagging momentum for AIDS prevention; industrialized countries have reduced such funding over the past few years. Michael Merson, director of WHO's Global Programme on AIDS, says overall funding from industrial countries is "insufficient", while WHO itself has "not raised nearly the resources it needs to".

Merson densies that the meeting is a "pledging" event. But France seems to have other ideas. Debré has proposed organizing a global AIDS 'téléthon' to raise funds. A similar event held in France recently raised FFr300 million (US\$56 million). Moreover, while France is one of the smallest contributors to UN AIDS programmes among the industrialized countries, it has promised FFr100 million to support the outcome of the summit and unblocked an extra FFr300 million for AIDS activities within bilateral cooperation programmes.

Although France's bilateral efforts are substantial, critics point out that these suffer from a lack of coordination as they fall within the remit of the ministries of foreign affairs and of cooperation, not the ministry of health. Critics add that such funds are often distributed - as in most countries on political rather than health-care criteria.

Other countries have remained remarkably silent about whether they intend to commit funds. Moreover, observers are concerned that such pledges may not be new money but simply money diverted from bilateral programmes.

Who will attend is another big unknown. Boutros Boutros Ghali, the UN secretary general, Jacques Delors, outgoing president of the European Commission and Helmut Kohl, the German chancellor are expected. But the United States will send Donna Shalala, secretary of state for health, rather than vice-president Al Gore (Shalala is expected to also visit the Institut Pasteur to bury the hatchet in the Gallo/Montagnier affair). Two weeks from the meeting, many invitations remain unanswered.

Merson hopes that the meeting will prove the sceptics wrong. "If we can present convincing initiatives to donor countries, we will get increased resources." The highest priority, he says, is to get better international cooperation between public authorities and private companies to promote research; through a coordinated approach to subsidizing corporate research, sponsoring clinical trials, and making any drug developed available to developing countries.

Research priorities, he says, are vaccines and vaginal microbicides. The latter could revolutionize efforts to prevent heterosexual transmission of HIV, he says, by protecting women, especially in developing countries, who cannot ensure that their partners use condoms (see Nature 366, 293; 1993).

WHO is also likely to use the meeting to publicize its recent authorization for the testing of HIV vaccines in developing countries (see page 313 ). The costs of the trialsestimated at tens of millions of dollarswill probably be met by Sweden and Japan, according to observers, pointing out that Hiroshi Nakajima, the director-general of WHO, is himself Japanese.

Another priority is to improve blood safety. In 1989, WHO tried to set up a Global Blood Safety Initiative, but this foundered because of lack of funding and inter-institutional tensions. After much internal political wrangling, WHO this month set up a planned "blood safety unit" (see Nature 369, 429 1994). Any new funds for blood safety coming from the summit are likely to go to this new unit, says Merson.

Declan Butler 